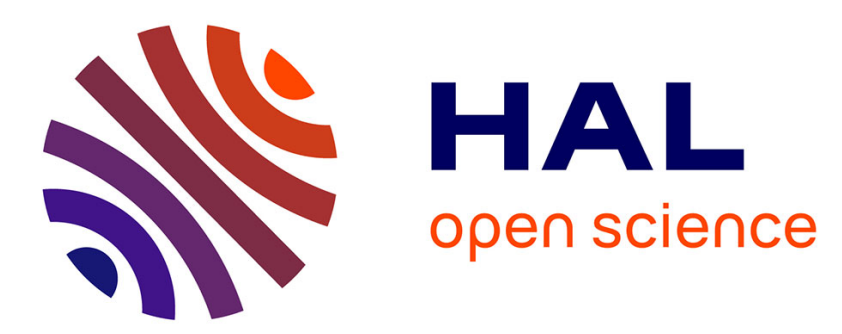

\title{
Acute loss of lung function without wheezing during bee venom immunotherapy
}

\author{
A. Chiriac, Fares Gouzi, J. Bousquet, P. Demoly
}

\section{To cite this version:}

A. Chiriac, Fares Gouzi, J. Bousquet, P. Demoly. Acute loss of lung function without wheezing during bee venom immunotherapy. Allergy, 2011, 66 (9), pp.1258-1259. 10.1111/j.1398-9995.2011.02603.x . inserm-02398249

\section{HAL Id: inserm-02398249 https://www.hal.inserm.fr/inserm-02398249}

Submitted on 7 Dec 2019

HAL is a multi-disciplinary open access archive for the deposit and dissemination of scientific research documents, whether they are published or not. The documents may come from teaching and research institutions in France or abroad, or from public or private research centers.
L'archive ouverte pluridisciplinaire HAL, est destinée au dépôt et à la diffusion de documents scientifiques de niveau recherche, publiés ou non, émanant des établissements d'enseignement et de recherche français ou étrangers, des laboratoires publics ou privés. 


\section{Allergy}

\section{Acute loss of lung function without wheezing during bee venom immunotherapy}

\begin{tabular}{|c|c|}
\hline Journal: & Allergy \\
\hline Manuscript ID: & ALL-2011-00106 \\
\hline Wiley - Manuscript type: & AllergyNet \\
\hline $\begin{array}{r}\text { Date Submitted by the } \\
\text { Author: }\end{array}$ & 05-Feb-2011 \\
\hline Complete List of Authors: & $\begin{array}{l}\text { Chiriac, Anca; University Hospital of Montpellier, Allergy Dept } \\
\text { Bousquet, Jean; chu montpellier, allergy } \\
\text { Demoly, Pascal; University Hospital of Montpellier, Allergy; Inserm, } \\
\text { U657 } \\
\text { GOUZI, Fares; INSERM ERI 25, Service central de Physiologie } \\
\text { Clinique }\end{array}$ \\
\hline Keywords : & bee venom, immunotherapy, bronchospasm, allergy, lung function \\
\hline
\end{tabular}




\title{
Acute loss of lung function without wheezing during bee venom immunotherapy
}

\author{
A Chiriac, F Gouzi, J Bousquet, P Demoly \\ Allergy department and Inserm U657, Département de Pneumologie et Addictologie, Hôpital Arnaud-de- \\ Villeneuve, University Hospital of Montpellier, 372, avenue du Doyen Gaston-Giraud, 34295 Montpellier cedex \\ 5 , France
}

Short title: Bronchospasm during VIT

Bee venom immunotherapy (VIT) induces systemic reactions $(1,2)$. Bronchospasm is one of the possible adverse events. However, objective measures of bronchoconstriction have never been published during VIT. In particular, it is not known whether bronchoconstriction is associated with symptoms and/or decrease in lung function.

One patient (male, 15 yrs of age), the son of a beekeeper, without atopic symptoms but with occasional exercise-induced wheezing, presented three times with mild dyspnea during bee stings. However, severe dyspnea occurred after the sting. He was evaluated for possible allergy to bee venom. The patient had negative skin prick tests to the GA ${ }^{2}$ LEN battery (3) but a positive intradermal skin test to bee venom $(0.01 \mu \mathrm{g} / \mathrm{ml}$, Stallergènes, Antony, France) and serum bee venom-specific IgE (>100 KUA/L, Phadia, Uppsala, Sweden).

VIT was initiated using Stallergènes extracts (Alyostal ${ }^{\circledR}$ Apis mellifera) with a cluster schedule (4). FEV 1 was monitored before and after VIT. During the second week of treatment, $15 \mathrm{~min}$ after a cumulative dose of $80 \mu \mathrm{g}(30+50 \mu \mathrm{g})$, the patient developed an erythema, pruritus of the face and neck with dyspnea, cough and rhinitis, without any wheezing. There was no clinical sign of a severe asthma exacerbation (5), pneumothorax or extra-thoracic obstruction. Normal breathing sounds were heard. FEV F $_{1}$ (with reliable expiratory manœuvres) was immediately measured and a drop from 4.751 to 3.71 (18.5\%) was found. However, there was only a marginal reduction of the $\mathrm{FEV}_{1} / \mathrm{FVC}$ from $100 \%$ to $91 \%$. The patient received an oral $\mathrm{H}_{1}$-antihistamine, $60 \mathrm{mg}$ prednisolone, 2 puffs of salbutamol, followed by an aerosol with terbutaline $(5 \mathrm{mg})$ and ipratropium $(0,5 \mathrm{mg})$, as well as oxygen via a mask $(5 \mathrm{l} / \mathrm{min})$. The dyspnea totally resolved after $20 \mathrm{~min}$, and the erythema and rhinitis persisted for 1 hour. $\mathrm{FEV}_{1}$ was measured $2 \mathrm{hrs}$ after the onset of the reaction and had returned to baseline value (4.7 1).

A week later, the patient received $50+50 \mu \mathrm{g}$ of venom and, within $20 \mathrm{~min}$, developed a severe reaction with facial erythema, cough and dyspnea. There was strictly no wheezing and no clinical sign of a severe asthma exacerbation (5). $\mathrm{FEV}_{1}$ dropped from 4.791 to 3.01 (37.3\%) with a proportional reduction of FVC. The patient received an oral $\mathrm{H}_{1}$-antihistamine, $60 \mathrm{mg}$ of prednisolone and two aerosols with terbutaline $(2 \times 5 \mathrm{mg})$ and ipratropium $(2 \times 0.5$ $\mathrm{mg}$ ) as well as oxygen via a mask (5 1/min). Adrenalin was not given. He completely recovered 30 min later. $\mathrm{FEV}_{1}$ was measured 2 hrs after the onset of the reaction and had returned to baseline value (4.87 1).

To our knowledge, this is the first case that has been described of a patient suffering from a severe bronchoconstriction characterized by objective measurement without wheezing during VIT. Other causes of respiratory distress were very unlikely (extrathoracic obstruction, pneumothorax, acute pulmonary oedema...). Recovery without adrenalin is not usually observed in upper airway obstruction. Acute bronchoconstriction characterized by a drop in 
$\mathrm{VC}$ and a normal $\mathrm{FEV}_{1} / \mathrm{FVC}$ ratio has been observed in metacholine challenge in patients with asthma (6), as shown by the increase in residual volume representing airway closure.

We consider it important to report this case since it may occur more commonly than expected, and supports the regular use of $\mathrm{FEV}_{1}$ or peak flow (PEFR) measurements in patients having suffered severe wheezing during a sting by hymenoptera. It is possible that non-atopic individuals react differently to asthmatics who may be more prone to wheezing.

1. Muller U, Mosbech H. Position paper: Immunotherapy with Hymenoptera venoms. Allergy 1993;48:S37-46.

2. Bonifazi F, Jutel M, Bilo BM, Birnbaum J, Muller U. Prevention and treatment of hymenoptera venom allergy: guidelines for clinical practice. Allergy 2005;60:1459-70.

3. Heinzerling LM, Burbach GJ, Edenharter G, Bachert C, Bindslev-Jensen C, Bonini S, et al. GA(2)LEN skin test study I: GA(2)LEN harmonization of skin prick testing: novel sensitization patterns for inhalant allergens in Europe. Allergy 2009;64:1498-506.

4. Tarhini H, Knani J, Michel FB, Bousquet J. Safety of venom immunotherapy administered by a cluster schedule. J Allergy Clin Immunol 1992;89:1198-9.

5. Bateman ED, Hurd SS, Barnes PJ, Bousquet J, Drazen JM, Fitzgerald M, et al. Global strategy for asthma management and prevention: GINA executive summary. Eur Respir J 2008;31:143-78.

6. Tantucci C, Guerini M, Boni E, Corda L, Pini L. Tidal Airway Closure During Bronchoconstriction in Asthma: Usefulness of Lung Volume Measurements. J Asthma 2010 Nov 1. [Epub ahead of print] 